\title{
Combined toxicity of endosulfan and ochratoxin-A in rats: histopathological changes
}

\author{
Shashi Nandar Kumar', Banajit Bastia', Avinash Gopal Telang², Karam Pal Singh², Rambir Singh ${ }^{3}$ and Arun Kumar Jain ${ }^{1 *}$
}

*Correspondence: drakjain@gmail.com

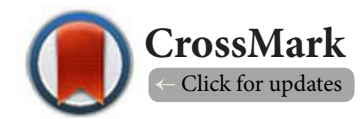

'Environmental Toxicology Lab, National Institute of Pathology (ICMR), Safdarjung Hospital Campus, New Delhi-110029, India. ${ }^{2}$ Centre for Animal Disease Research and Diagnosis (CADRAD), Indian Veterinary Research Institute, Izatnagar, Bareilly-243122, (U.P.), India.

${ }^{3}$ Institute of Biomedical Sciences, Bundelkhand University, Kanpur Road, Jhansi 284001, Uttar Pradesh, India.

\begin{abstract}
The aim of this study was to examine and compare the toxic effects of endosulfan and ochratoxin-A (OTA), individually and in combination, in adult male rats with respect to histopathological changes over 30 days of treatment. Adult male Wistar rats were randomly allotted to four groups (individual treatments, combination and control) of 10 rats each and fed OTA@4 ppm in feed (Group-I), endosulfan@ @ mg/kg BW in corn oil by oral gavage (Group-II), and endosulfan with OTA in combination (Group-III) daily for 30 days. Group IV was kept as control and fed toxin free feed. After 30 days of treatment, tissues were collected in $10 \%$ buffered formalin for histopathological studies. The hematoxylin and eosin stained paraffin sections showed varying degree of degenerative and necrotic changes in kidneys and liver which were more severe in OTA treated rats in comparison to endosulfan fed group. However, the changes observed in group III rats, which received both OTA and endosulfan were even more pronounced than those observed in rats fed OTA or endosulfan alone. The present findings suggest that OTA and endosulfan had additive effects which may play an important role in pathogenesis.
\end{abstract}

Keywords: Ochratoxin-A, endosulfan, toxicity, histopathology, liver, kidney

\section{Introduction}

Mycotoxins can be found in nearly all agricultural commodities, such as cereals (maize, wheat, oats and barley) and cereal by-products. Moulds or fungi and their associated mycotoxins have been shown to be present on all crops in varying amounts, depending on the climatic conditions. Correct storage of feeds and feedstuffs is critical in preventing mould growth. While improper storage of feed stuff may result in excessive mycotoxin contamination, current agricultural practices with emphasis on widespread use of pesticides may cause pesticide contamination of agricultural items which become toxic for consumption. These contaminations can cause serious problems, both for human health as well as for the economic value of crops.

Endosulfan is a persistent, toxic, broad-spectrum organochlorine insecticide and acaricide used on food and non-food crops. It has been enlisted as one of the persistent organic pollutants (POPs) that is largely used in agriculture, viticulture and horticulture [1]. Endosulfan contamination in blood, fat, milk, vegetables, cashew leaves, soil and water has been reported from Padre village of Kasargod district of Kerala, India [2,3]. It causes toxic effect on almost all the organs of both humans and animals including the liver, lung, central nervous system, genital system, pancreas etc [4]. Endosulfan acts as an endocrine disruptor, causing reproductive and developmental damage; and has also been reported to cause immune suppression and cancer in experimental animals [1,5-10].

Ochratoxin-A (OTA) is one of most toxic mycotoxins produced by numerous varieties of Aspergillus and Penicillium [11,12]. Worldwide contamination of OTA has been reported in a wide range of foods, including cereals and peanuts [13], poultry feeds [14], feedstuffs [15], green coffee beans [16], cocoa beans [17], wine grapes ([18], dried vine fruits [19] and beer [20]. It is also reported toxic manifestations of OTA include nephrotoxicity, teratogenicity, immunotoxicity, carcinogenicity, and mutagenicity [21]. OTA is suspected to be responsible for human Balkan Endemic Nephropathy (BEN) [21,22]. Thus, kidney is considered to be one of the main target organs of OTA [23]. Due to its ubiquitous occurrence in a range of foodstuffs, the complete 
avoidance of OTA exposure is virtually impossible [23-25].

Further, in real life, organisms are concurrently exposed to several i.e., more than one pollutants or toxins. Therefore, the present study was aimed to examine the pathological changes in liver and kidney of adult male rats in case of combined exposure to OTA and Endosulfan.

\section{Materials and methods}

\section{Production and analysis of OTA}

Aspergillus ochraceus NRRL-3174 was initially procured from National Centre for Agriculture Utilization Research, Peoria, Illinois, USA. It was grown on sterilized maize as per the method described by Trenk and coworkers [26]. The extraction and clean up of the toxin sample were done by AOAC method [27] and quantification of OTA was done with the help of TLC scanner (CAMAG, Switzerland).

\section{Preparation of toxicated feed}

Cultured maize powder containing known amount of OTA was added to basal ration (which were tested negative for presence of contaminating mycotoxins) in such proportion that the final concentration of OTA was adjusted to $4 \mathrm{mg} \mathrm{kg}^{-1}$ feed. Aliquots were taken from the mixed diet and the toxin was further quantified to ensure proper mixing of the toxin.

\section{Dosing of endosulfan}

Endosulfan (>99.98\% pure crystalline Technical grade Shriram Chemicals Ltd., India) was dissolved in corn oil (vehicle) at a concentration of $5 \mathrm{mg} \mathrm{kg}^{-1}$ body weight and oral gavage was given to male rats, daily for 30 days. Fresh solution of endosulfan was prepared on each day of treatment. Control animals received an equal volume of corn oil similar to those treated with endosulfan.

\section{Experimental plan}

Forty sexually mature male Wistar rats (Age: 7 to 8 weeks; weight: $180 \pm 20 \mathrm{~g}$ ), procured from the Laboratory Animal Resource (LAR) section of the Indian Veterinary Research Institute were maintained on standard feed and water available ad libitum. After 1 week of acclimatization period, the animals were randomly distributed in to 4 groups of ten rats each and treated for 30 days as follows: Group-I animals were given with a diet containing OTA at the level of $4 \mathrm{mg} \mathrm{kg}^{-1}$ feed; Group-II animals received endosulfan at a concentration of $5 \mathrm{mg} \mathrm{kg}^{-1}$ body weight by oral gavage; Group-III animals received both OTA ( $4 \mathrm{mg} \mathrm{kg}^{-1}$ feed) and endosulfan ( $5 \mathrm{mg}$ $\mathrm{kg}^{-1}$ body weight) and Group-IV animals were fed a standard mycotoxins-free basal diet. All the experimental procedure and sacrifice of rats were carried out as per the approved guidelines of Institutional Animal Ethics Committee (IAEC) and Committee for the Purpose of Control and Supervision of Experiments on Animals (CPCSEA).

\section{Pathological changes}

The liver and kidney of all the groups were examined for gross morphological and pathological changes. Wet organ weights were recorded before collecting tissue samples for processing. Representative tissue samples were collected in $10 \%$ buffered formalin for histopathological studies. The tissues were properly processed and embedded in paraffin wax. The sections were stained with hematoxylin and eosin stain [28] and were then examined under light microscope.

\section{Statistical analysis}

Data generated during the study were suitably analyzed using student's 't'test to detect differences between means among groups. All analyses were performed with GraphPad InStat software (San Diago, USA). All the statements of significance were based on a probability level of $p<0.05$.

\section{Results}

Gross lesions and relative weight of kidney and liver Macroscopic examination of rats fed with OTA or Endosulfan or their combination for 30 days, showed focal areas on liver surface. Liver was slightly pale and molted. There was a significant reduction in relative weight of kidney and liver in Group-I (OTA-treated) and Group-III (combination of OTA and endosulfan diet) as compared to those of controls (Table 1). The reduction was highly significant in Group-III.

\section{Ochratoxin A (OTA) treatment Kidney}

As compared to controls (Figure 1), the proximal convoluted tubules in OTA-treated animals showed degenerative changes along with the presence of pinkish homogenous mass in the lumen (Figure 2). Some of the tubules showed pyknotic and karyorrhectic nuclei. Vascular congestion was observed both in cortex and medulla. Several glomeruli showed widening of Bowman's space with deposition of proteinaceous mass. Tubular lumen was found to be obliterated due to degeneration and swelling of lining epithelial cells.

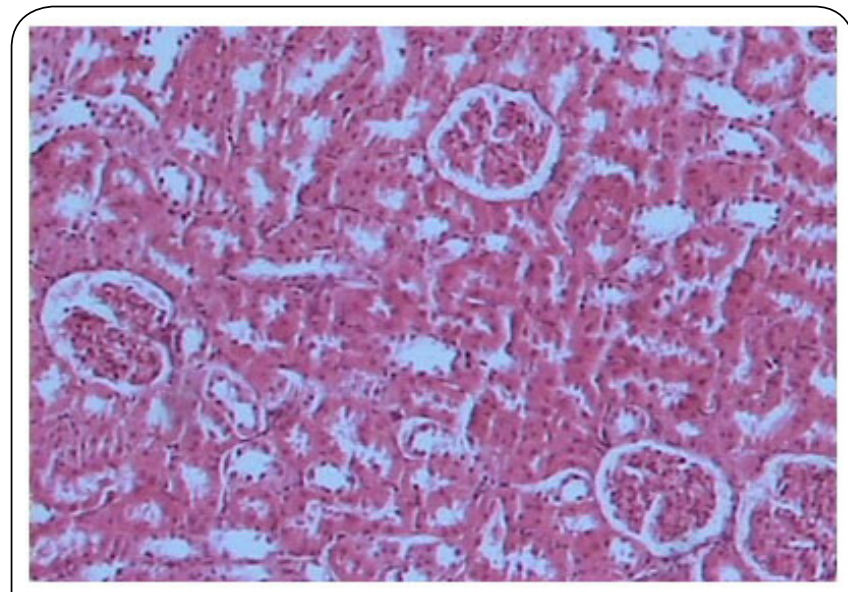

Figure 1. Kidney section showing normal glomeruli and proximal and distal convoluted tubules $\mathrm{H} \& \mathrm{E} \times 100$. 
Table 1. Effect of OTA and Endosulfan (ES) administered alone and in combination on relative weight of liver and kidney of adult male rats.

\begin{tabular}{llllll}
\hline Group $\rightarrow$ & Control & OTA & $\begin{array}{l}\text { Endosulfan } \\
(\text { ES })\end{array}$ & $\begin{array}{l}\text { Combination } \\
(\text { OTA+ES) }\end{array}$ & Significance \\
\hline Organs & \multicolumn{5}{c}{ Organ weight (gm) expressed as mean \pm SE $(\mathbf{n}=10)$} \\
\hline Liver & $3.93 \pm 0.24^{\mathrm{b}}$ & $3.27 \pm 0.66^{\mathrm{a}}$ & $3.57 \pm 0.18^{\mathrm{ab}}$ & $3.12 \pm 0.11^{\mathrm{a}}$ & $\mathrm{P}<0.05$ \\
Kidney & $1.03 \pm 0.07^{\mathrm{b}}$ & $0.79 \pm 99^{\mathrm{a}}$ & $0.86 \pm 0.04^{\mathrm{b}}$ & $0.70 \pm 0.064$ & $\mathrm{P}<0.05$ \\
\hline
\end{tabular}

Mean bearing at least one common superscript do not differ significantly between groups.

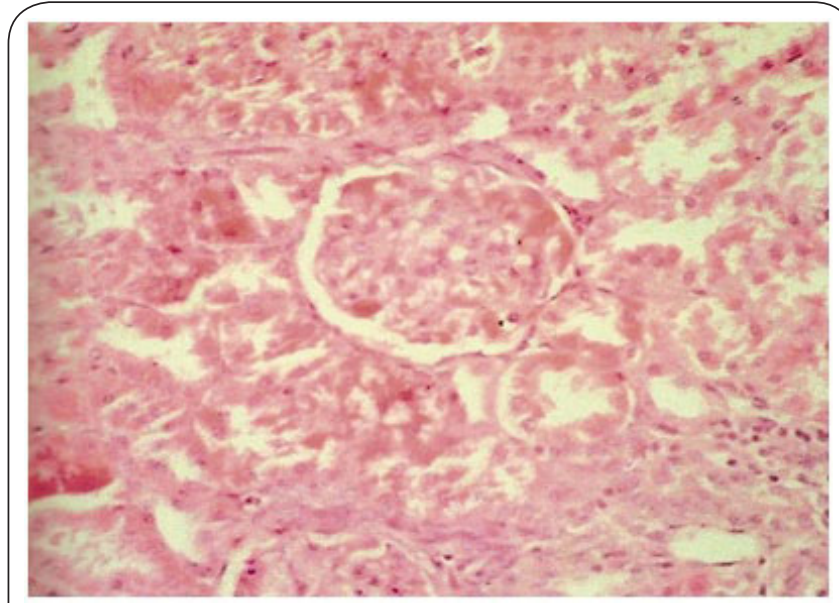

Figure 2. OTA-treated kidney: Marked necrotic and degenerative changes in proximal convoluted tubules. Note the detachment of necrosed lining cells $H \& E \times 200$.

\section{Liver}

Rats fed on toxin-free diet showed normal liver architecture (Figure 3). In comparison, hepatocytes in rats fed with OTA (Group-l) showed degenerative and necrotic changes with granular cytoplasm (Figure 4). Cytoplasm in most of the

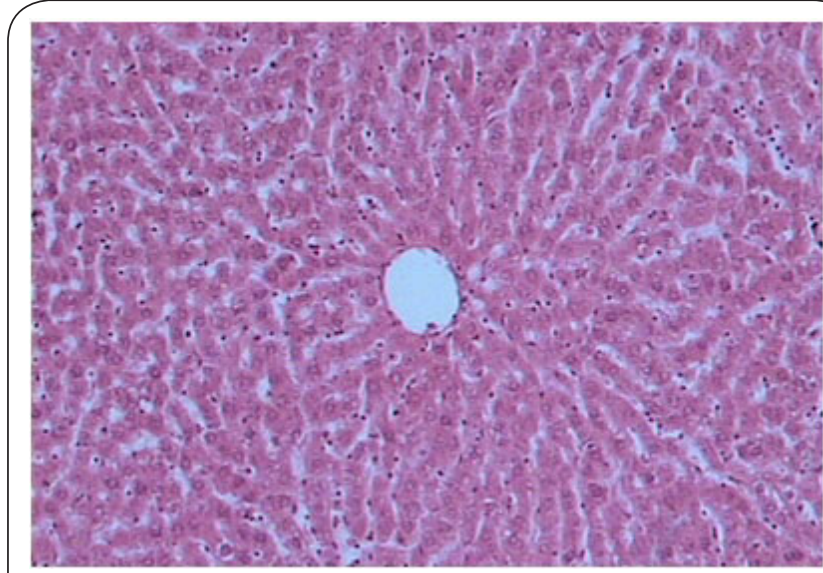

Figure 3. Liver section showing normal architectural arrangement of hepatic cords. The hepatocytes also appear normal with centrally placed nucleus and eosinophilic cytoplasm $\mathrm{H} \& \mathrm{E} \times 100$.

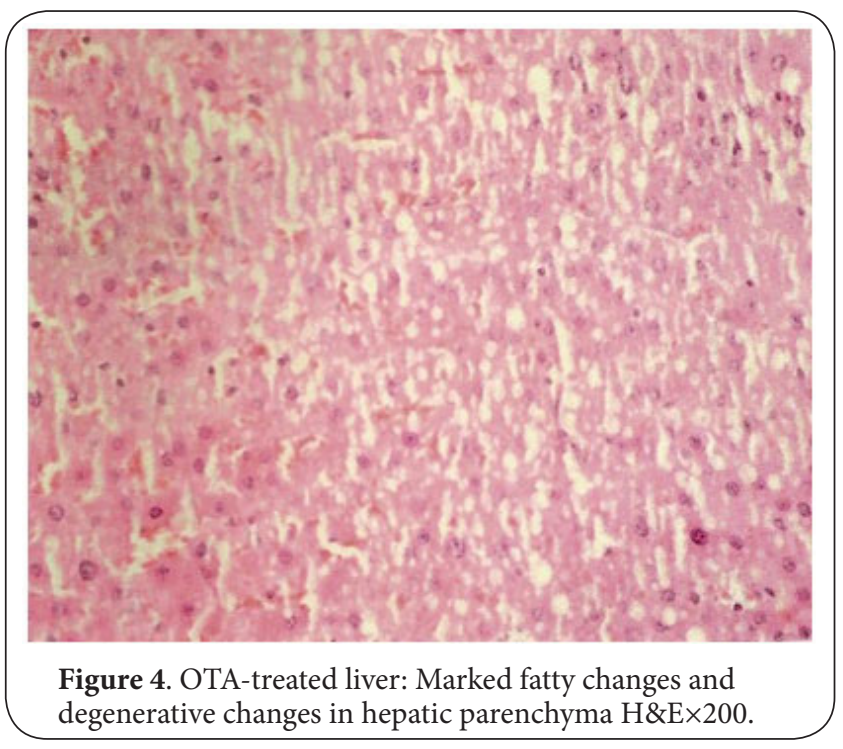

hepatocytes was pale or less stained. Hepatic sinusoids along with central and portal veins showed mild to moderate congestion. Mild to moderate fatty changes were observed in hepatocytes of centrilobular area (Figure 4).

\section{Endosulfan treatment \\ Kidney}

Proximal convoluted tubules in group-II, revealed degeneration and necrosis of the lining cells. The tubular lumen showed presence of detached necrosed pinkish mass (Figure 5). Inter-tubular blood vessels were mildly congested.

\section{Liver}

Hepatocytes in endosulfan-toxicated group-II rats, showed mild degeneration with granular cytoplasm in comparison to OTA alone (Figure 6).

\section{Endosulfan+OTA combination treatment Kidney}

In group-III, proximal convoluted tubules exhibited degenerative changes with pinkish granules in the cytoplasm and vacuolations in the lining of epithelial cells (Figure 7). The swelling of the cells resulted into the obstruction of the lumen. Some of the glomeruli showed presence of pinkish homogenous 


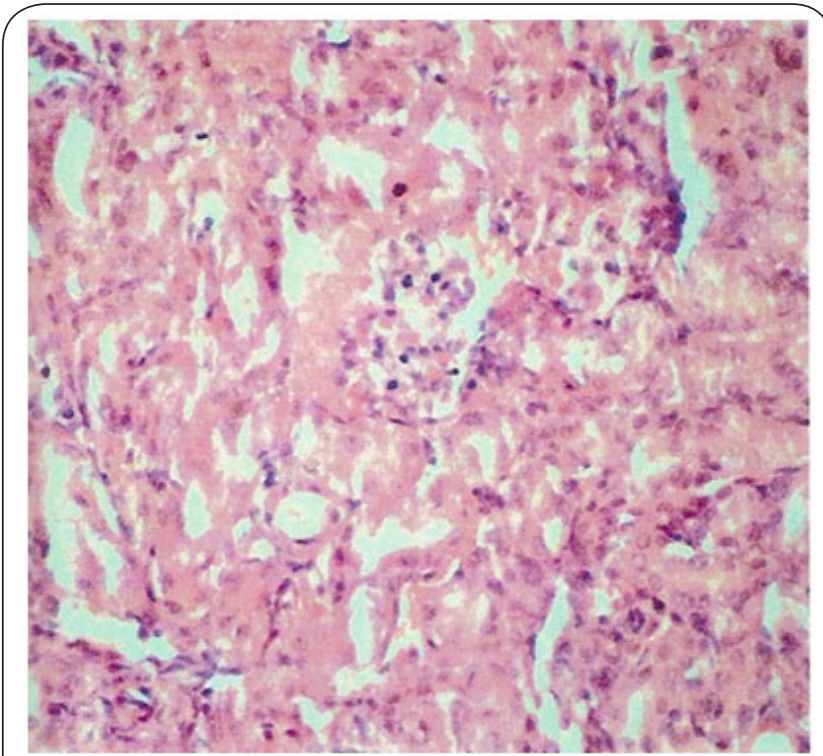

Figure 5. Endosulfan-treated kidney: Marked necrotic changes in the proximal convoluted tubules. Necrosed lining cells detached into the lumen $\mathrm{H} \& \mathrm{E} \times 200$.

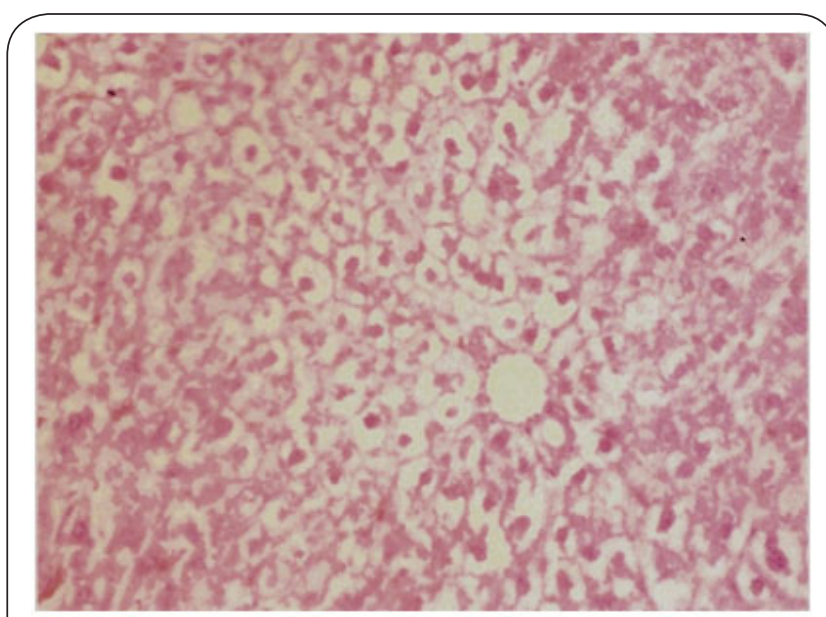

Figure 6. Endosulfan-treated liver: Hepatocytes shows loss of cytoplasm, giving the appearance of emptiness H\&E×200.

proteinaceous mass and vacuoles in the capillary tuft with increased Bowman's space (Figure 7). The inter-tubular blood vessels were occasionally congested.

\section{Liver}

Hepatic sinusoids and portal veins in group-III animals, showed mild to moderate vascular congestion. Swelling with fine granules in the cytoplasm and occasional double nuclei was observed in hepatocytes. Hepatic lobules revealed degeneration with presence of small to large fatty vacuoles in hepatocytes pushing the nucleus towards periphery (Figure 8). These fatty changes were mostly confined around the central vein. At places mononuclear cell reaction was noticed in the

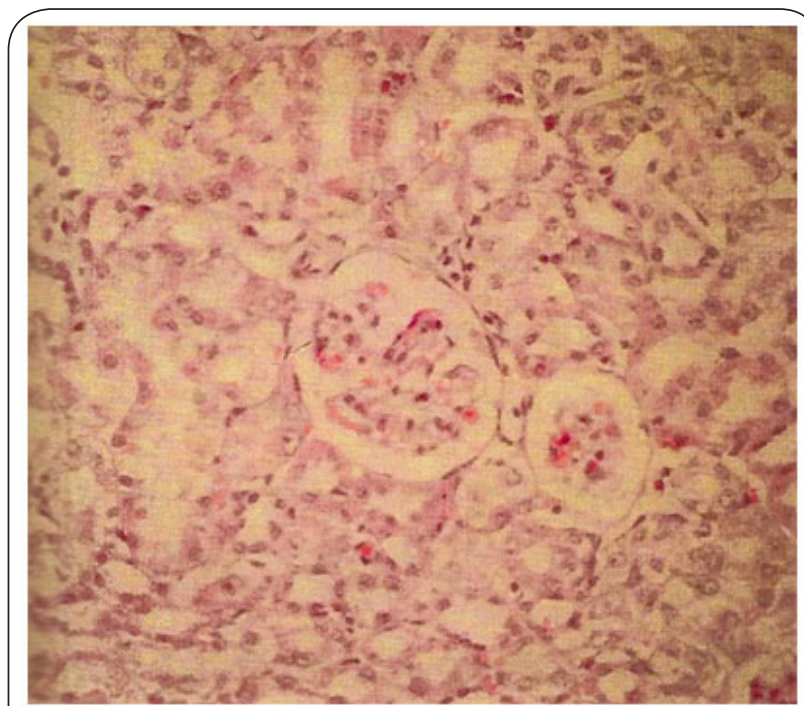

Figure 7. OTA and Endosulfan-treated kidney: Glomeruli with widened Bowman's space; degenerated convoluted tubules and presence of homogenous mass in the lumen $\mathrm{H} \& \mathrm{E} \times 200$

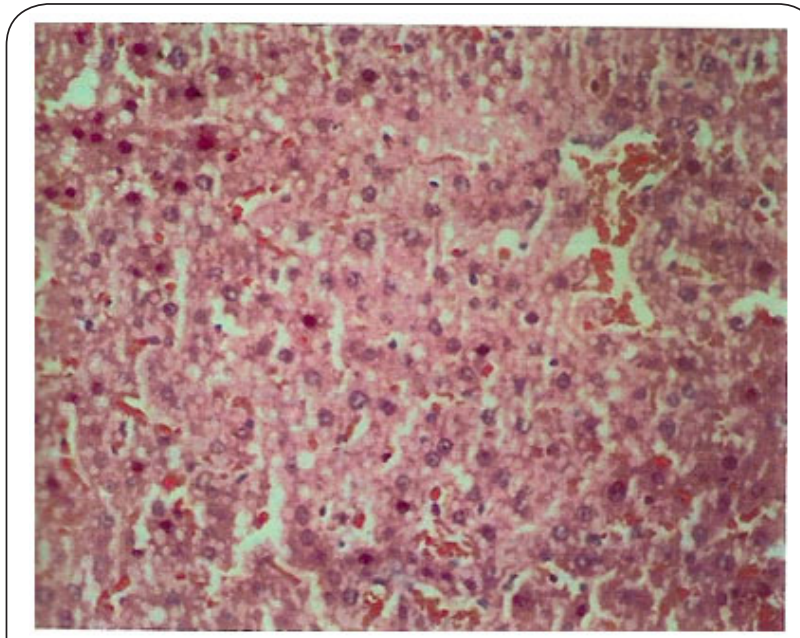

Figure 8. OTA and Endosulfan-treated liver: Hepatic parenchyma shows marked necrosis and fatty vacuoles in the hepatocytes with focal vascular congestion $\mathrm{H} \& \mathrm{E} \times 200$.

centre of the portal lobules around the portal triad. Focal areas of necrosis with isolated hepatocytes were seen in hepatic parenchyma at few places (Figure 8).

\section{Discussion}

Gross lesion observed were swollen and slightly mottled liver and slightly pale kidneys. The relative weight to these organs was also found to be decreased. The changes in liver and kidneys were comparatively more intense in combination group as compared to OTA or Endosulfan alone. These observations were in accordance with the findings of earlier 
Kumar et al. Journal of Histology \& Histopathology 2015,

worker [29-31]. The absolute and relative organ weight of liver and kidney were in agreement with the observations of [32] in rats and [33] in chicks administered with Endosulfan. Contrary to our observations on organ weights, earlier workers [34-36] reported increased organ weight of liver and kidneys. These discrepancies could be due to many factors such as age, sex and strain of animals, the influence of the vehicle or difference in the administration regimen. OTA and Endosulfan alone caused pale discoloration of liver and kidneys, increased fragility of liver, which could be attributed to degenerative changes as detected on histopathological examination. OTA and Endosulfan are known to be hepatotoxic and nephrotoxic. These effects have been seen in our experimental animal rat. The changes in liver were of degenerative in nature including fatty changes and vascular congestion. Similar changes have also been reported by earlier workers in different species of animals i.e., rat $[29,30,36]$, rabbits $[31,37-39]$ and poultry [40]. The degenerative and vascular changes observed in kidney tubules and renal corpuscles were in consensus with the findings of earlier workers $[\mathbf{2 9 , 3 6 , 4 0 , 4 1 ]}$. The gross or microscopic changes observed in the present study may be classified as mild, probably due to low dose of ochratoxin-A or endosulfan. The histopathological changes in kidneys explain, at least in parts, the functional alterations (increased level of creatinine and blood urea nitrogen) recorded in serum analysis of these experimental rats in a previous study [42]. From the present study it was concluded that OTA and Endosulfan are potentially toxic to liver and kidney in combination as compared to their toxic effects alone.

\section{Competing interests}

The authors declare that they have no competing interests.

Authors' contributions

\begin{tabular}{|l|c|c|c|c|c|c|}
\hline Authors' contributions & SNK & BB & AGT & KPS & RS & AKJ \\
\hline Research concept and design & $\checkmark$ & -- & $\checkmark$ & -- & $\checkmark$ & -- \\
\hline Collection and/or assembly of data & $\checkmark$ & -- & -- & $\checkmark$ & -- & -- \\
\hline Data analysis and interpretation & $\checkmark$ & -- & -- & $\checkmark$ & -- & -- \\
\hline Writing the article & $\checkmark$ & $\checkmark$ & -- & -- & -- & $\checkmark$ \\
\hline Critical revision of the article & -- & -- & -- & -- & -- & $\checkmark$ \\
\hline Final approval of article & -- & -- & -- & -- & -- & $\checkmark$ \\
\hline Statistical analysis & -- & -- & $\checkmark$ & $\checkmark$ & -- & $\checkmark$ \\
\hline
\end{tabular}

\section{Acknowledgement}

The researchers would like to acknowledge the help extended by In-charge, Division of Pathology, Indian Veterinary

Research Institute.

\section{Publication history}

Editor: Lingyan Wang, Oregon Health \& Science University, Portland. EIC: Gaetano Giuseppe Magro, University of Catania, Italy. Received: 29-Sep-2015 Final Revised: 03-Nov-2015

Accepted: 13-Nov-2015 Published: 23-Nov-2015

\section{References}

1. Du H, Wang M, Dai H, Hong W, Wang J, Weng N, Nie Y and Xu A. Endosulfan isomers and sulfate metabolite induced reproductive toxicity in Caenorhabditis elegans involves genotoxic response genes. Environ Sci Technol. 2015; 49:2460-8. | Article | PubMed

2. Omnipresent Poison. I Website

3. Ramesh A and Vijayalakshmi A. Environmental exposure to residues after aerial spraying of endosulfan: residues in cow milk, fish, water, soil and cashew leaf in Kasargode, Kerala, India. Pest Manag Sci. 2002; 58:1048-54. | Article | PubMed

4. O. Ozmen. Pathology of Endosulfan. in Pesticides in the Modern WorldEffects of Pesticides Exposure, M. Stoytcheva, Ed. InTech. 2011.

5. Gupta PK and Gupta RC. Pharmacology, toxicology and degradation of endosulfan A review. Toxicology. 1979; 13:115-30. | Article | PubMed

6. Sutherland TD, Home I, Weir KM, Russell RJ and Oakeshott JG. Toxicity and residues of endosulfan isomers. Rev Environ Contam Toxicol. 2004; 183:99-113. | Article | PubMed

7. N. D. Singh, A. K. Sharma, P. Dwivedi, Kumar M and R. D. Patil. Immunosuppressive effect of combined citrinin and endosulfan toxicity in pregnant Wistar rats. Vet. Arh. 2011; 81. | Article

8. Singh ND, Sharma AK, Dwivedi P, Patil RD and Kumar M. Citrinin and endosulfan induced teratogenic effects in Wistar rats. J Appl Toxicol. 2007; 27:143-51. | Article | PubMed

9. Singh ND, Sharma AK, Dwivedi P, Patil RD and Kumar M. Citrinin and endosulfan induced maternal toxicity in pregnant Wistar rats: pathomorphological study. J Appl Toxicol. 2007; 27:589-601. | Article | PubMed

10. S. N. Kumar A. G. Telang R. D. Patil A. K. Jain and K. P. Singh. Cytogenetic Effects of Combined Ochratoxin A and Endosulfan in Rats. J. Environ. Anal. Toxicol. 2014; 4:1. I Article

11. Baudrimont I, Sostaric B, Yenot C, Betbeder AM, Dano-Djedje S, Sanni A, Steyn PS and Creppy EE. Aspartame prevents the karyomegaly induced by ochratoxin A in rat kidney. Arch Toxicol. 2001; 75:176-83. | Article | PubMed

12. Al-Anati $L$ and Petzinger E. Immunotoxic activity of ochratoxin $A$. J Vet Pharmacol Ther. 2006; 29:79-90. | Article | PubMed

13. Magnoli C, Hallak C, Astoreca A, Ponsone L, Chiacchiera S and Dalcero AM. Occurrence of ochratoxin A-producing fungi in commercial corn kernels in Argentina. Mycopathologia. 2006; 161:53-8. | Article | PubMed

14. Rosa CA, Ribeiro JM, Fraga MJ, Gatti M, Cavaglieri LR, Magnoli CE, Dalcero AM and Lopes CW. Mycoflora of poultry feeds and ochratoxinproducing ability of isolated Aspergillus and Penicillium species. Vet Microbiol. 2006; 113:89-96. | Article | PubMed

15. Magnoli C, Hallak C, Astoreca A, Ponsone L, Chiacchiera SM, Palacio $G$ and Dalcero $A$. Surveillance of toxigenic fungi and ochratoxin $A$ in feedstuffs from Cordoba Province, Argentina. Vet Res Commun. 2005; 29:431-45. | Article | PubMed

16. Romani S, Sacchetti G, Chaves Lopez C, Pinnavaia GG and Dalla Rosa M. Screening on the occurrence of ochratoxin $A$ in green coffee beans of different origins and types. J Agric Food Chem. 2000; 48:3616-9. | Article I PubMed

17. Serra Bonvehi J. Occurrence of ochratoxin A in cocoa products and chocolate. J Agric Food Chem. 2004; 52:6347-52. I Article I PubMed

18. Magnoli C, Violante M, Combina M, Palacio G and Dalcero A. Mycoflora and ochratoxin-producing strains of Aspergillus section Nigri in wine grapes in Argentina. Lett Appl Microbiol. 2003; 37:179-84. | Article | PubMed

19. Magnoli C, Astoreca A, Ponsone L, Combina M, Palacio G, Rosa CA and Dalcero AM. Survey of mycoflora and ochratoxin $A$ in dried vine fruits from Argentina markets. Lett Appl Microbiol. 2004; 39:326-31. | Article I PubMed

20. Medina A, Jimenez M, Gimeno-Adelantado JV, Valle-Algarra FM and Mateo R. Determination of ochratoxin A in beer marketed in Spain by liquid chromatography with fluorescence detection using lead hydroxyacetate as a clean-up agent. J Chromatogr A. 2005; 1083:7-13. | Article | PubMed

21. Pfohl-Leszkowicz A and Manderville RA. Ochratoxin A: An overview on toxicity and carcinogenicity in animals and humans. Mol Nutr Food Res. 
Kumar et al. Journal of Histology \& Histopathology 2015,

http://www.hoajonline.com/journals/pdf/2055-091X-2-22.pdf

doi: 10.7243/2055-091X-2-22

2007; 51:61-99. | Article | PubMed

22. Gekle $M$, Schwerdt $G$, Freudinger R, Mildenberger S, Wilflingseder D, Pollack V, Dander M and Schramek H. Ochratoxin A induces JNK activation and apoptosis in MDCK-C7 cells at nanomolar concentrations. J Pharmacol Exp Ther. 2000; 293:837-44. | Article | PubMed

23. Liang R, Shen XL, Zhang B, Li Y, Xu W, Zhao C, Luo Y and Huang K. Apoptosis signal-regulating kinase 1 promotes Ochratoxin A-induced renal cytotoxicity. Sci Rep. 2015; 5:8078. | Article | PubMed

24. Kuiper-Goodman T and Scott PM. Risk assessment of the mycotoxin ochratoxin A. Biomed Environ Sci. 1989; 2:179-248. | Article | PubMed

25. Simon P, Godin M and Fillastre JP. Ochratoxin a: a new environmental factor which is toxic for the kidney? Nephrol Dial Transplant. 1996; 11:2389-91. | Article | PubMed

26. Trenk HL, Butz ME and Chu FS. Production of ochratoxins in different cereal products by Aspergillus ochraceus. Appl Microbiol. 1971; 21:10325. | PubMed Abstract | PubMed Full Text

27. P. Cunniff and Association of Official Analytical Chemists. Official methods of analysis of the AOAC International. Washington (D.C.): AOAC International. 1995.

28. L. G. Luna. Manual of histologic staining methods of the Armed Forces Institute of Pathology. 1968.

29. Choudhary N, Sharma M, Verma P and Joshi SC. Hepato and nephrotoxicity in rat exposed to endosulfan. J Environ Biol. 2003; 24:305-8. | Article | PubMed

30. K. Prasanna, A. K. Sharma, P. Dwivedi, C. C. Satheesh and A. G. Telang. Pathogenesis of ochratoxin $A$ induced nephropathy in rats with special reference to oxidative damage, cytokine profile and ultrastructural changes. Indian J. Vet. Pathol. 2007; 31:1-10. | Article

31. Wangikar PB, Dwivedi P, Sharma AK and Sinha N. Effect in rats of simultaneous prenatal exposure to ochratoxin $A$ and aflatoxin B1. II. Histopathological features of teratological anomalies induced in fetuses. Birth Defects Res B Dev Reprod Toxicol. 2004; 71:352-8. | Article I PubMed

32. Dortant PM, Peters-Volleberg GW, Van Loveren H, Marquardt RR and Speijers GJ. Age-related differences in the toxicity of ochratoxin $A$ in female rats. Food Chem Toxicol. 2001; 39:55-65. | Article | PubMed

33. N. V. Kurkure, A. G. Bhandarkar, M. V. Joshi, R. D. Sadekar and S. S. Bhagwat. Immunosuppressive and histotoxic effects of endosulphan in chicks. Indian J. Anim. Sci. India. 1993.

34. Munro IC, Moodie CA, Kuiper-Goodman T, Scott PM and Grice HC. Toxicologic changes in rats fed graded dietary levels of ochratoxin $A$. Toxicol Appl Pharmacol. 1974; 28:180-8. | Article | PubMed

35. Kiran $\mathrm{R}$ and Varma MN. Biochemical studies on endosulfan toxicity in different age groups of rats. Toxicol Lett. 1988; 44:247-52. | Article | PubMed

36. C. C. Satheesh, A. K. Sharma, K. Prasanna and P. Dwivedi. Ultrastructural changes in kidneys and liver in experimentally induced ochratoxicosis in wister rats. Indian J. Vet. Pathol. India. 2004. | Article

37. M. S. Mir, P. Dwivedi and K. Charan. Ochratoxin A induced acute toxicity in rabbits. 1999.

38. M. S. Mir and P. Dwivedi. Clinical studies on experimental subacute ochratoxicosis in rabbits. Indian J Vet Pathol. 2000; 24:99-101.

39. Wangikar PB, Dwivedi P, Sinha N, Sharma AK and Telang AG. Teratogenic effects in rabbits of simultaneous exposure to ochratoxin $A$ and aflatoxin B1 with special reference to microscopic effects. Toxicology. 2005; 215:37-47. | Article | PubMed

40. Dwivedi $P$, Burns RB and Maxwell MH. Ultrastructural study of the liver and kidney in ochratoxicosis A in young broiler chicks. Res Vet Sci. 1984; 36:104-16. | Article | PubMed

41. Hack R, Ebert E and Leist KH. Chronic toxicity and carcinogenicity studies with the insecticide endosulfan in rats and mice. Food Chem Toxicol. 1995; 33:941-50. | Article | PubMed

42. S. N. Kumar, A. G. Telang, K. P. Singh, B. Bastia and A. K. Jain. Toxic Manifestation of Endosulfan and Ochratoxin- A in Adult Male Rats. MOJ Toxicol. 2015; 1:00012. | Pdf

\section{Citation:}

Kumar SN, Bastia B, Telang AG, Singh KP, Singh R and Jain AK. Combined toxicity of endosulfan and ochratoxin-A in rats: histopathological changes. $J$ Histol Histopathol. 2015; 2:22.

http://dx.doi.org/10.7243/2055-091X-2-22 